\title{
Scoping the Enantioselective Desymmetrization of a Poorly Water-Soluble Diester by Recombinant Pig Liver Esterase
}

Meissner, Murray P.; Süss, Philipp; Brundiek, Henrike; Woodley, John M.; von Langermann, Jan

Published in:

Organic Process Research And Development

Link to article, DOI:

10.1021/acs.oprd.8b00277

Publication date:

2018

Document Version

Peer reviewed version

Link back to DTU Orbit

Citation (APA):

Meissner, M. P., Süss, P., Brundiek, H., Woodley, J. M., \& von Langermann, J. (2018). Scoping the

Enantioselective Desymmetrization of a Poorly Water-Soluble Diester by Recombinant Pig Liver Esterase.

Organic Process Research And Development, 22(11), 1518-1523. https://doi.org/10.1021/acs.oprd.8b00277

\section{General rights}

Copyright and moral rights for the publications made accessible in the public portal are retained by the authors and/or other copyright owners and it is a condition of accessing publications that users recognise and abide by the legal requirements associated with these rights.

- Users may download and print one copy of any publication from the public portal for the purpose of private study or research.

- You may not further distribute the material or use it for any profit-making activity or commercial gain

- You may freely distribute the URL identifying the publication in the public portal 


\section{Full Paper}

Subscriber access provided by DTU Library

\section{Scoping the Enantioselective Desymmetrization of a Poorly Water-Soluble Diester by Recombinant Pig Liver Esterase}

Murray P. Meissner, Philipp Süss, Henrike Brundiek, John M. Woodley, and Jan von Langermann

Org. Process Res. Dev., Just Accepted Manuscript • DOI: 10.1021/acs.oprd.8b00277 • Publication Date (Web): 16 Oct 2018

Downloaded from http://pubs.acs.org on October 23, 2018

\section{Just Accepted}

"Just Accepted" manuscripts have been peer-reviewed and accepted for publication. They are posted online prior to technical editing, formatting for publication and author proofing. The American Chemical Society provides "Just Accepted" as a service to the research community to expedite the dissemination of scientific material as soon as possible after acceptance. "Just Accepted" manuscripts appear in full in PDF format accompanied by an HTML abstract. "Just Accepted" manuscripts have been fully peer reviewed, but should not be considered the official version of record. They are citable by the Digital Object Identifier (DOI®). "Just Accepted" is an optional service offered to authors. Therefore, the "Just Accepted" Web site may not include all articles that will be published in the journal. After a manuscript is technically edited and formatted, it will be removed from the "Just Accepted" Web site and published as an ASAP article. Note that technical editing may introduce minor changes to the manuscript text and/or graphics which could affect content, and all legal disclaimers and ethical guidelines that apply to the journal pertain. ACS cannot be held responsible for errors or consequences arising from the use of information contained in these "Just Accepted" manuscripts. 


\title{
Scoping the Enantioselective Desymmetrization of a
}

\section{Poorly Water-Soluble Diester by Recombinant Pig}

\section{Liver Esterase}

\author{
Murray P. Meissner, ${ }^{\theta, \beta}$ Philipp Süss, ${ }^{\S}$ Henrike Brundiek, ${ }^{\S}$ John M. Woodley, ${ }^{*}, \theta$ Jan von \\ Langermann ${ }^{*}, \dagger$
}

${ }^{\theta}$ Technical University of Denmark (DTU), Department of Chemical and Biochemical Engineering, Søltofts Plads, Building 229, 2800 Lyngby, Denmark

ßOxford Biotrans Ltd., 127 Olympic Avenue, Milton Park, OX14 4SA, United Kingdom §Enzymicals AG, Walther-Rathenau-Str. 49a, 17489 Greifswald, Germany

University of Rostock, Institute of Chemistry, Biocatalytic Synthesis Group, Albert-EinsteinStr. 3a, 18059 Rostock, Germany

\section{Corresponding Authors}

jw@kt.dtu.dk (John M. Woodley) and jan.langermann@,uni-rostock.de (Jan von Langermann) 
ABSTRACT. Previously, the biocatalytic desymmetrization of dimethyl cyclohex-4-ene-cis-1,2dicarboxylate to $(1 S, 2 R)$-1-(methoxycarbonyl)cyclohex-4-ene-2-carboxylic acid, an important intermediate towards the synthesis of biologically active molecules, had been well-characterized in terms of $\mathrm{pH}$ and temperature optima and several aspects of process performance. Eventually this promising reaction could convert $200 \mathrm{mM}\left(40 \mathrm{~g} \cdot \mathrm{L}^{-1}\right)$ of substrate with $>99.5 \%$ e.e. using the recombinant pig liver esterase, ECS-PLE06, at a scale of $8.8 \mathrm{~L}$. However, the precise influence of substrate concentration and the poorly water-soluble nature of the substrate (approximately $60 \mathrm{mM}$ in water at $25{ }^{\circ} \mathrm{C}$ for structurally similar dimethyl 1,4-cyclohexanedicarboxylate) remained elusive. Therefore, this work focuses on using a recently published methodology based on reaction trajectory analysis to identify mass transfer limitations in this reaction. With the constraints of mass transfer on space-time yield considered, it was possible to evaluate and improve biocatalyst yield (mass of product per mass of biocatalyst) through the use of higher substrate concentrations. Ultimately the complete conversion of approximately $75 \mathrm{~g} \cdot \mathrm{L}^{-1}$ substrate was achieved in $3.65 \mathrm{~h}$ yielding an excellent productivity of $20 \mathrm{~g} \cdot \mathrm{L}^{-1} \cdot \mathrm{h}^{-1}$ with a biocatalyst yield of $4.36 \mathrm{~g} \cdot \mathrm{g}_{\text {biocat }}{ }^{-1}$. This work also highlights the simplicity of applying a reaction trajectory analysis methodology, importance of scale during reaction characterizations and identifies future directions for reaction improvement to address substrate supply and product inhibition/deactivation.

KEYWORDS. Biocatalysis; recombinant Pig Liver Esterase (PLE); Reaction Scoping; Kinetic Characterizations; Substrate Mass Transfer 


\section{TOC-figure}

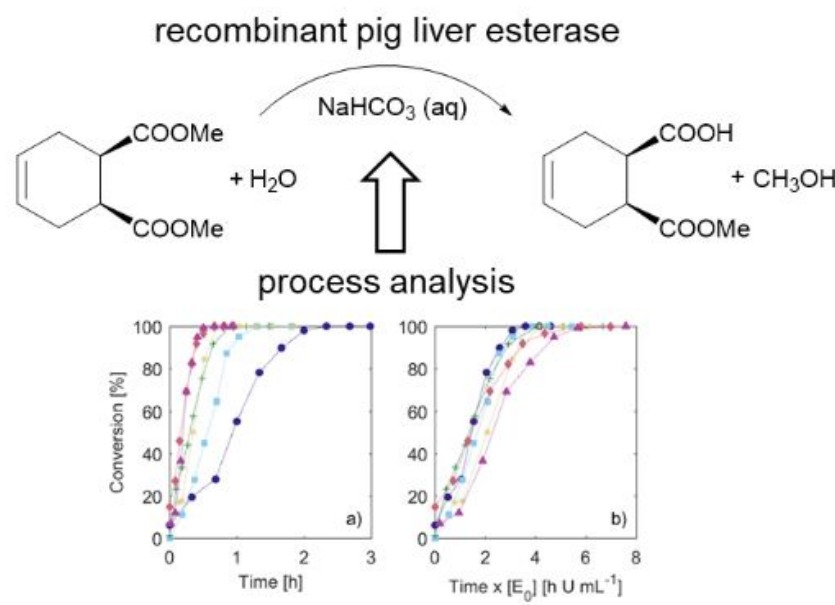




\section{Introduction}

Biocatalysis has become an established branch of chemistry in its own right resulting from the excellent stereo-, regio- and enantioselectivity of biocatalysts even under mild reaction conditions. ${ }^{1,2}$ Consequentially, biocatalysts can realize sustainable manufacturing processes, satisfying 10 of the 12 principles of green chemistry: waste prevention and high atom efficiency (avoiding the formation of by-products) through their high selectivity, less hazardous syntheses, safer solvents (most often carried out in water), and low energy demand due to their operation under mild process conditions, their origin from renewable sugar feedstocks through fermentation, avoidance of derivatization, their nature as catalysts and not stoichiometric reagents, the ability to apply real-time process analytics to prevent waste, and most importantly, their inherent safety. ${ }^{3}$ Additionally, these traits frequently (although not always) infer better process economics. Finally, biocatalysts can be further improved by protein engineering, offering an additional degree of freedom towards process design. Such improvements are gained through tailoring the amino acid sequences of enzymes to enhance stability, activity or selectivity. ${ }^{4}$ Indeed, numerous biocatalytic processes have been successfully commissioned to date, using these approaches. ${ }^{5-7}$

Conventional catalysis is most often performed in homogeneous gas-phase reactors or organic solvents, where reaction scale-up is often dependent on adequate heat transfer and appropriate reactor design. For biocatalysis, under mild conditions (ambient temperature, near neutral $\mathrm{pH}$ and in aqueous-based media), this is less relevant. Instead, the conditions of the reaction become important and biocatalytic reaction performance can be estimated (or "scoped") using a standard set of process performance measures (metrics). ${ }^{8}$ These metrics may be benchmarked against industrial requirements, while the importance and value of each respective metric may differ depending on the value of the product and target market. It is advantageous to be able to quantify 
these metrics at a scale as small as possible, in order to allow fast and efficient process evaluation using the smallest possible amounts of (often expensive) materials. However, it turns out that in many cases these metrics do not scale well. Understanding these limitations of scale-up for biocatalysis helps address them during process development.

A major reason for performance changes across scales is due to substrate mass transfer limitations. It is well known that enzymes require at least some water to be present in their environment to be active. ${ }^{9}$ Since organic substrates and products of synthetic interest are frequently poorly water-soluble, this results in mass transfer limitations. ${ }^{10}$ This applies also to gas-liquid systems, such as the important enzyme-catalyzed oxidations ${ }^{11}$, due to the particularly low watersolubility of oxygen. Interestingly, the scale-dependence of gas-liquid mass transfer is different from liquid-liquid mass transfer (see Table 1). Mixing is a function of power input, which can vary significantly with scale. ${ }^{12}$ More specifically, it is easier to thoroughly mix a smaller volume to achieve good dispersion (high power input per unit volume) than it is to mix a large volume. As dispersion increases, so does the specific interfacial area $\left(\mathrm{m}^{-1}\right)$ of the second phase component (smaller gas bubbles or liquid droplets), which leads to improved mass transfer. However, when considering gas-liquid mass transfer, an even greater influence is the increased gas hold-up at larger scales, allowing an increase in overall volumetric mass transfer coefficient $\left(k_{L} a\right) .{ }^{13}$ In contrast, liquid-liquid systems are not affected by hold-up because the volumetric component remains in the reaction volume unlike gases, which pass through a reactor. Furthermore, liquidliquid systems have the ability to be emulsified by adding surfactants resulting in a homogeneous medium, which being independent of mixing thereby makes them scale-independent. While solidliquid systems are not in focus in this work, similar parallels can be drawn, although they are less 
dependent on mixing to ensure a high interfacial area and are rather influenced more by initial particle size.

Table 1. Effect of scale on gas-liquid and liquid-liquid mass transfer.

\begin{tabular}{|c|c|c|c|c|}
\hline & \multicolumn{2}{|c|}{ Gas-Liquid Mass Transfer } & \multicolumn{2}{c|}{ Liquid-Liquid Mass transfer } \\
\hline & $\begin{array}{c}\text { Dispersion (i.e. } \\
\text { bubble size) }\end{array}$ & Hold-up $^{a}$ & $\begin{array}{c}\text { Dispersion (i.e. } \\
\text { droplet size / } \\
\text { coalescence) }\end{array}$ & Hold-up \\
\hline Small-scale & $\uparrow$ & $\downarrow \downarrow$ & $\uparrow$ & N/A \\
\hline Large-scale & $\downarrow$ & $\uparrow \uparrow$ & $\downarrow$ & N/A \\
\hline $\begin{array}{l}{ }^{a} \text { The extent of effect of hold-up on mass transfer is more or less pronounced for plug-flow or } \\
\text { well-mixed regimes, respectively. }{ }^{b}\end{array}$ \\
\hline \multicolumn{5}{|l}{} \\
\hline
\end{tabular}

It is therefore important to consider the scale at which reaction assessments are performed because some mass transfer limited reactions (e.g. gas-liquid systems) will not proceed at the same rate at a small-scale as at larger scales. The most important metrics to evaluate under these circumstances are the biocatalyst yield and product concentration. These indicate if the catalyst is sufficiently efficient and if enough product can be generated in a reasonable amount of time. Timecourse measurements are an effective means to assess reaction performance and gauge these metrics. Recently, a method making use of comparing normalized time-course measurements (or reaction trajectories) under different experimental conditions was used to distinguish mass transfer limitations from other kinetic effects (e.g. enzyme stability, substrate affinity or intrinsic activity). ${ }^{14}$ Additionally, the mechanism of enzyme deactivation or potential substrate/product inhibition can also be identified using such time-course progressions. ${ }^{14-17}$ Time-course progressions also give indication of the expected productivity of a reaction, and already at this 
stage, reactions that proceed too slowly may be earmarked for improvement. Naturally, only metrics assessed at a larger scale can be considered true process metrics, although understanding how to gauge a reflection of the metrics at smaller scales is invaluable to the effectiveness of process development.

In this work, a recently published procedure of reaction scoping for biocatalysis ${ }^{14}$ was applied to the enantioselective desymmetrization of dimethyl cyclohex-4-ene-cis-1,2-dicarboxylate (1) to $(1 S, 2 R)$-1-(methoxycarbonyl)cyclohex-4-ene-2-carboxylic acid (2) catalyzed by recombinant pig liver esterase (rPLE; ECS-PLE06; Scheme 1). ${ }^{18}$ The monoester product of this reaction is of value as a pharmaceutical intermediate towards the synthesis of biologically active molecules ${ }^{19}$ (some examples are shown in Scheme 1$)^{20}$, the antibiotic plantencin ${ }^{21}$ as well as some active pharmaceutical ingredients in treatments towards $\mathrm{HIV}^{22}$ and cytomegalovirus (Herpes) ${ }^{23}$. Previously, this reaction and enzyme were characterized in terms of $\mathrm{pH}$ and temperature optima as well as reaction performance. ${ }^{18,24,25} \mathrm{~A}$ simple method of $\mathrm{pH}$ control was implemented that made use of inexpensive sodium bicarbonate degradation in the presence of the carboxylic acid product 2, thereafter forming $\mathrm{CO}_{2}$ and passing from the reaction medium. This was found to be more effective than conventional titration of base to control the $\mathrm{pH}$. In addition, the $\mathrm{pH}$ remains stable within non-saturated bicarbonate solutions. Eventually this promising reaction showed adequate performance to convert substrate concentrations of $200 \mathrm{mM}\left(40 \mathrm{~g} \cdot \mathrm{L}^{-1}\right)$ with an enantiomeric excess of $>99.5 \% .{ }^{18}$ However, this reaction performance came from a series of improvised experiments and the bottleneck towards large-scale production was not determined. On this basis, we argued that it would be valuable to perform a bottleneck identification using reaction trajectory analysis ${ }^{14}$ to determine the major process limitation. Using time-course measurements in this way we argued it would be possible to distinguish the dominating bottleneck to the required performance of ECS- 
PLE06 under given conditions: either enzyme kinetics, enzyme stability or, more likely, substrate mass transfer. With this limitation identified, the reaction could be further up-scaled and its suitability for process implementation assessed.

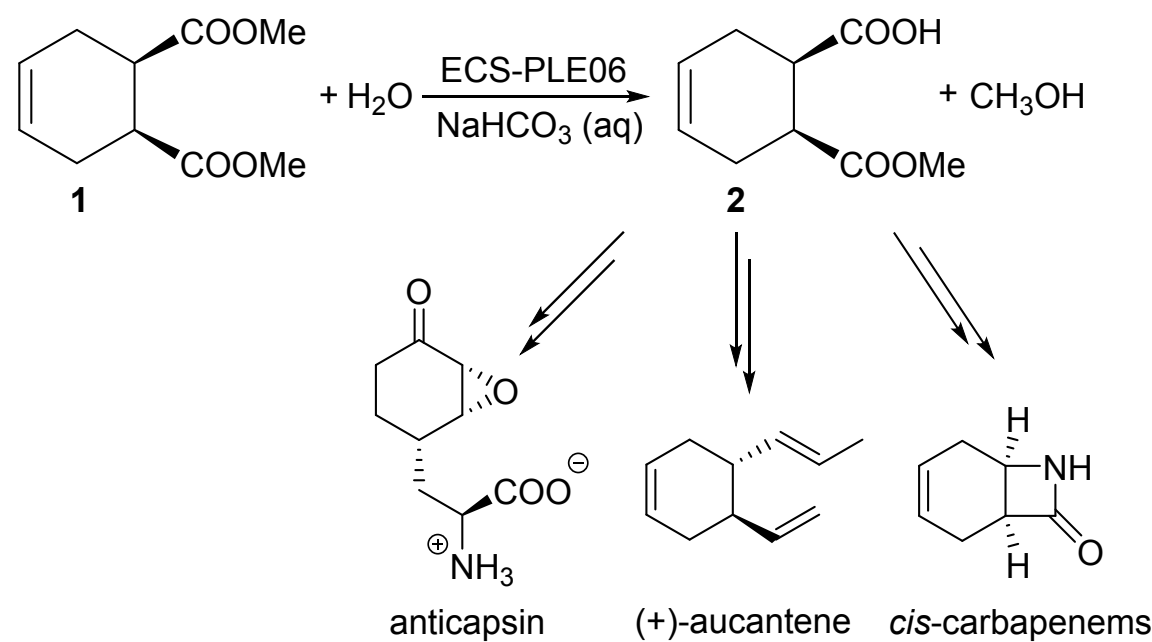

Scheme 1. Desymmetrization of diester 1 to $(1 S, 2 R)$-monoester $\mathbf{2}$ catalyzed by recombinant pig liver esterase (ECS-PLE06).

\section{Results and Discussion}

Understanding the influence of the poorly water-soluble substrate on this system initially required a series of time-course experiments with varying enzyme concentrations (expressed as dosed activities) to identify potential mass transfer limitations. With this limitation on reaction rate considered, process performance metrics were assessed. Further scale-up was then considered with the goal of maximizing product concentration.

The first step in this systematic procedure was to elucidate the major reaction limitation by varying enzyme loadings at a fixed, moderate substrate dose. Figure 1a shows representative timecourse progressions at different enzyme doses at a fixed substrate concentration of $80 \mathrm{mM}$. Normalizing the time axis by the varied parameter (enzyme activity) reveals that the reaction becomes substrate mass transfer limited at enzyme doses above ca. $6 \mathrm{U} \cdot \mathrm{mL}^{-1}$, since the reaction 
trajectories diverge (Figure 1b). Interestingly, the product was found to have a beneficial effect by better dispersing the substrate in the reaction medium since it acts as an emulsifier. Likewise, methanol was also formed as a by-product, which would (at higher concentrations) help improve substrate solubility in the medium (and thereby reduce mass transfer limitations). The slight improvement in reaction rate due to these factors can be observed after initial product formation, especially at the lowest enzyme doses.
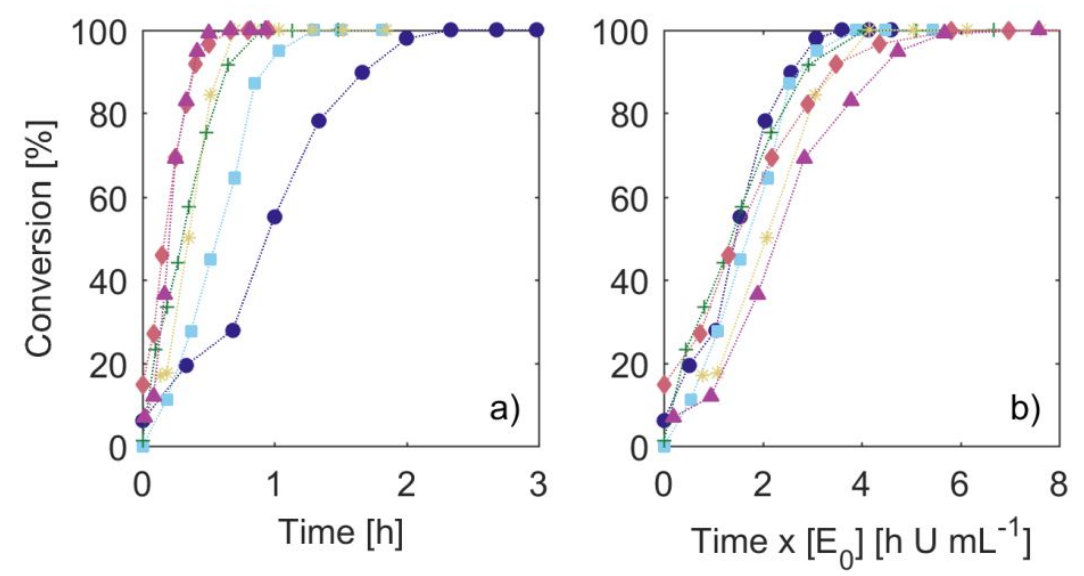

Figure 1. (a) Conversion as a function of time for the ECS-PLE06 catalyzed reaction of $80 \mathrm{mM}$ diester $\mathbf{1}$ to monoester $\mathbf{2}$ using $40 \mathrm{~mL}$ saturated $\mathrm{NaHCO}_{3}$ as a buffer $(\mathrm{pH} 8.15)$ at $40{ }^{\circ} \mathrm{C}$ in a stirred round bottom flask (left). (b) Data replotted with the x-axis normalized by enzyme concentration to reveal the major process limitation (right). ECS-PLE06 concentrations, $\left[\mathrm{E}_{0}\right]$, were varied as follows: • $-1.54 \mathrm{U} \cdot \mathrm{mL}^{-1},-2.99 \mathrm{U} \cdot \mathrm{mL}^{-1},+-4.50 \mathrm{U} \cdot \mathrm{mL}^{-1},{ }^{*}-5.94 \mathrm{U} \cdot \mathrm{mL}^{-1},-8.72 \mathrm{U} \cdot \mathrm{mL}^{-1}$, $\Delta-11.37 \mathrm{U} \cdot \mathrm{mL}^{-1}$

Figure 2 is a plot of space-time yield and biocatalyst yield as a function of enzyme activity. According to Figure 2, the upper limit of productivity due to substrate mass transfer limitations is $21 \mathrm{~g} \cdot \mathrm{L}^{-1} \cdot \mathrm{h}^{-1}$. Clearly, the expected linear response of space-time yield to enzyme activity no longer holds beyond this point, indicating a non-enzyme related limitation. On the other hand, biocatalyst 
yield appears to improve at lower enzyme concentrations because the same amount of substrate is still converted, even though the reactions take longer. Another way of improving the biocatalyst yield is to increase the substrate loading thereby converting more substrate with the same amount of enzyme. In this way, a better reflection of biocatalyst yield is obtained because, in reality, industrial processes should operate with the highest possible space-time yield in order to afford cost-effective processes (shorter batches and smaller reaction volumes). However, the most representative biocatalyst yield should still be evaluated under conditions where the reaction is not kinetically limited. This is especially important to consider in cases such as this, which are limited by liquid-liquid mass transfer.

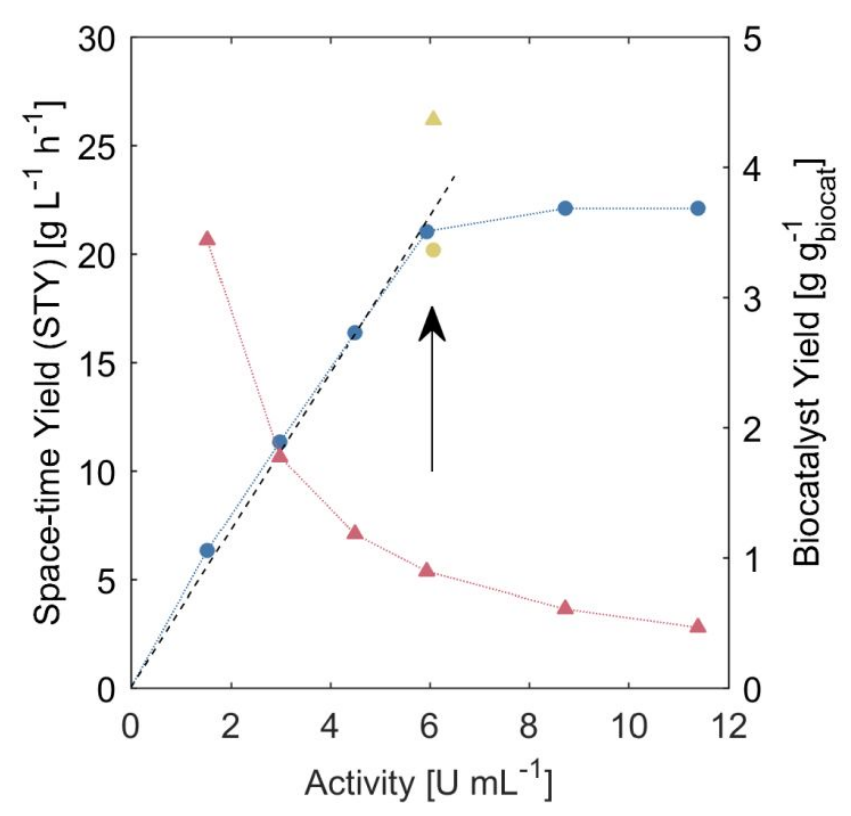

Figure 2. Space-time yield (STY; blue $\bullet$ ) and biocatalyst yield (red $\mathbf{\Delta}$ ) as a function of rPLE dose (presented as activity) after the full conversion of $80 \mathrm{mM}$ substrate. The dashed line indicates linearity through the origin. Data in yellow are those obtained after the full conversion of $400 \mathrm{mM}$ substrate. 
Hence, the substrate concentration was increased 5 -fold $(400 \mathrm{mM})$ and an enzyme dose of $6 \mathrm{U} \cdot \mathrm{mL}^{-1}$ was maintained because mass transfer limitations only occurred at higher enzyme concentrations. Full conversion and no kinetic limitations were observed at this higher substrate concentration, which was confirmed by the overlap of trajectories on a normalized time axis plot (Figure 3). The resultant 4.9-fold improvement in biocatalyst yield from 0.89 to $4.36 \mathrm{~g} \cdot \mathrm{g}_{\text {biocat }}{ }^{-1}$ at an almost identical maximum space-time yield is shown in Figure 2.

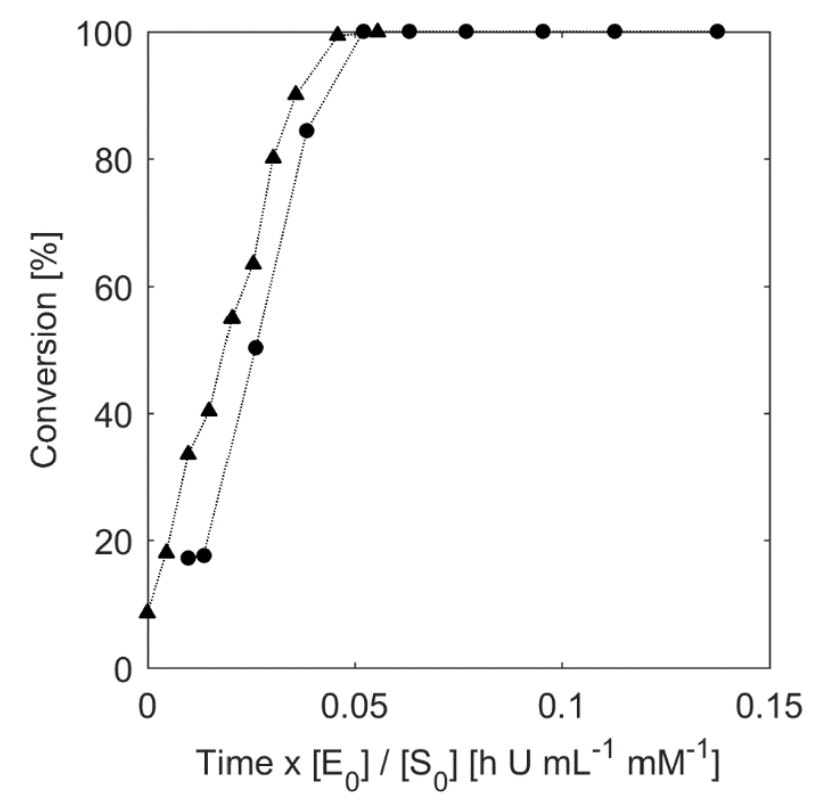

Figure 3. Reaction with $80 \mathrm{mM}$ substrate $(\bullet)$ and $400 \mathrm{mM}$ substrate $(\boldsymbol{\Delta})$ in $40 \mathrm{~mL}$ saturated $\mathrm{NaHCO}_{3}$ buffer $(\mathrm{pH} 8.15)$ at $40{ }^{\circ} \mathrm{C}$ both with an enzyme dose of $6 \mathrm{U} \mathrm{mL}^{-1}$ on a normalized timeaxis plot.

In order to investigate the potential of further increasing substrate concentration, it was necessary to marginally increase the scale of reaction by operating in a $250 \mathrm{~mL}$ stirred tank reactor. At this scale, better control and measurement of the reaction environment was made possible through defined stirring, temperature and $\mathrm{pH}$ control. Substrate concentrations greater than $500 \mathrm{mM}$ caused the enzyme to agglomerate and denature. Therefore, three $400 \mathrm{mM}$ batch doses of 1 were supplied 
at $3 \mathrm{~h}$ intervals in a fed-batch manner to mimic the previous reaction profiles observed at smaller scale. Nevertheless, full conversion was not reached even after $24 \mathrm{~h}$ (data not shown). In order to rule out potential substrate inhibition caused by too high single substrate concentration doses, a constant feed of substrate at $5.81 \mathrm{~g} \cdot \mathrm{h}^{-1}$ was instead supplied to the reactor by use of a syringe pump. This would hypothetically result in a calculated $1.19 \mathrm{M}\left(225 \mathrm{~g} \cdot \mathrm{L}^{-1}\right)$ product and a space-time yield of $22.0 \mathrm{~g} \cdot \mathrm{L}^{-1} \cdot \mathrm{h}^{-1}$ in a $9 \mathrm{~h}$ reaction, assuming the reaction is not limited. However, during a fedbatch reaction, product formation ceased after $7 \mathrm{~h}$, after which substrate accumulated at a rate equal to that of the pump feed rate (Figure 4a). Since the mass balance of substrate and product closed throughout the reaction, this result indicated that indeed the reaction had stopped after $400 \mathrm{mM}$ product formation (Figure 4b). We postulated therefore that either enzyme stability or product inhibition could be the cause. In order to confirm this, the end-point reaction medium was dosed with a fresh $6 \mathrm{U} \cdot \mathrm{mL}^{-1}$ of ECS-PLE06 and left to incubate at $40{ }^{\circ} \mathrm{C}$ for $48 \mathrm{~h}$. Conversion was only marginally improved by approximately $10 \%$ (data not shown) indicating that product inhibition or product induced deactivation was the most likely cause of activity loss. 

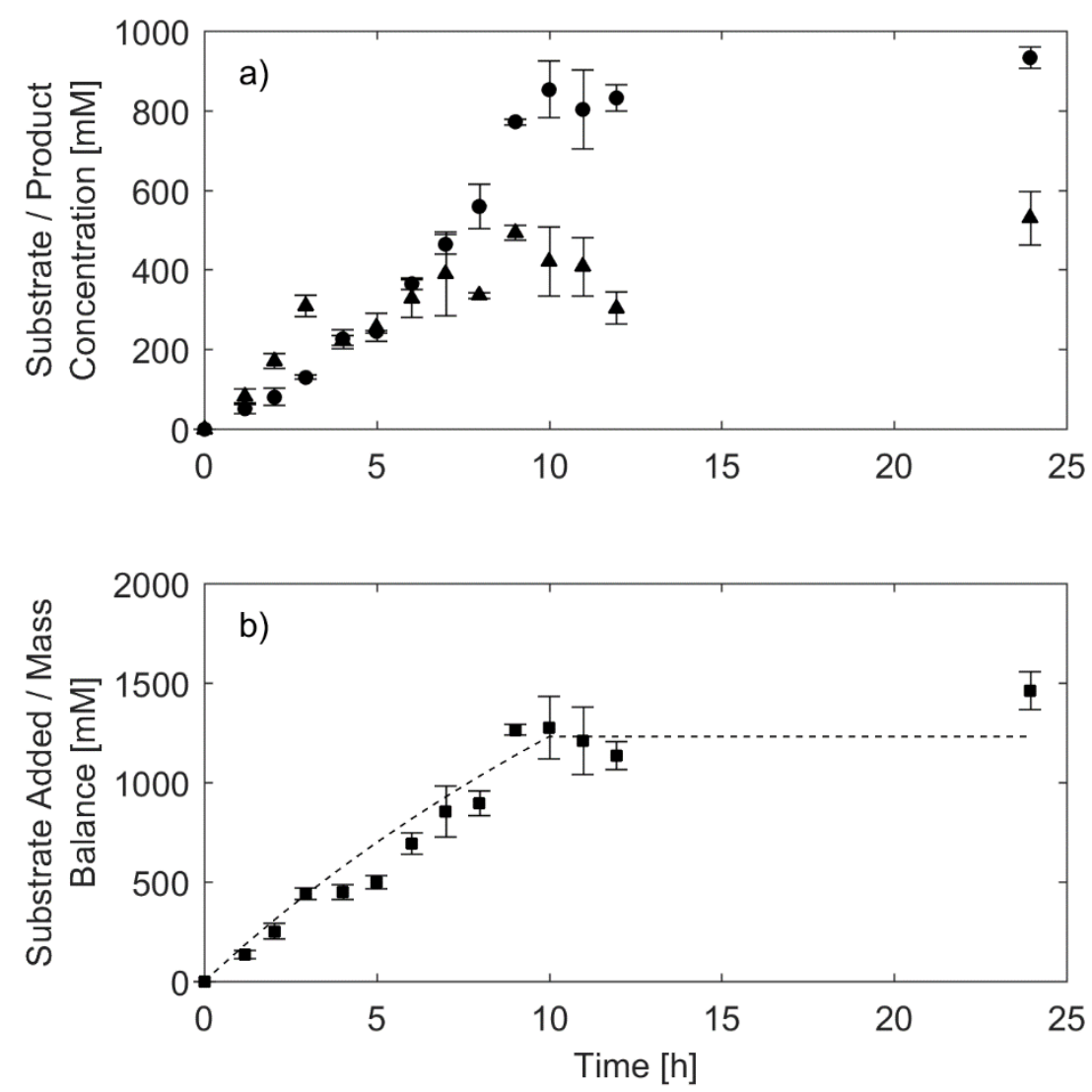

Figure 4. (a) Fed-batch conversion of $1.2 \mathrm{M}$ diester $\mathbf{1}(\bullet)$ to monoester $\mathbf{2}(\boldsymbol{\Delta})$ in a $250 \mathrm{~mL}$ (end volume) stirred tank reactor. $\mathrm{pH}$ was maintained with saturated $\mathrm{NaHCO}_{3}$ buffer $(\mathrm{pH} 8.15)$ at $40{ }^{\circ} \mathrm{C}$ and included an enzyme dose of $6 \mathrm{U} \cdot \mathrm{mL}^{-1}$ (above). (b) Mass balance corresponding to the sum of substrate and product in the reaction medium $(\bullet)$ the actual fed-batch rate of substrate supply to the reactor by a syringe pump (below). Error bars reflect $95 \%$ confidence intervals $(n=3)$.

In order to test this further, the time-dependent stability of ECS-PLE06 was evaluated with respect to temperature $\left(40{ }^{\circ} \mathrm{C}\right)$, high buffer strength solutions (saturated $\left.\mathrm{NaHCO}_{3}\right)$, and by-product methanol concentrations of up to $5 \%(\mathrm{v} / \mathrm{v})$ (corresponding to a high molar concentration of ca. 1.3 M; Figure 5). ECS-PLE06 showed a negligible activity loss after $24 \mathrm{~h}$ in the presence of all environmental factors. Furthermore, the enzyme gained activity whilst being incubated in $\mathrm{NaHCO}_{3}$ 
buffer and methanol, which might point towards an affinity of ECS-PLE06 for strongly buffered environments containing methanol. This confirmed that the remaining limitation to be addressed was product inhibition or product induced deactivation.

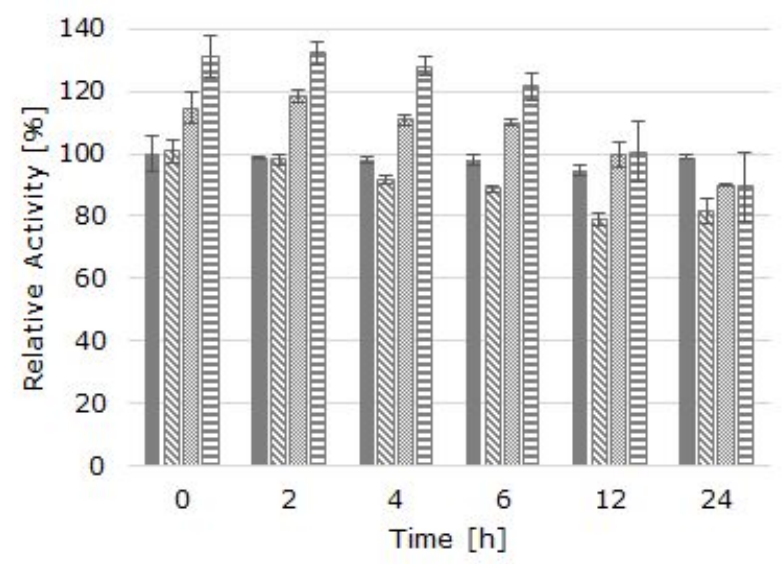

Figure 5. Stability of ECS-PLE06 as a function of time at room temperature in $50 \mathrm{mM}$ phosphate buffer at $\mathrm{pH} 7.5$ (control, solid bars), at $40{ }^{\circ} \mathrm{C}$ in $50 \mathrm{mM}$ phosphate buffer ( $\mathrm{pH} 7.5$; diagonal striped bars), at $40{ }^{\circ} \mathrm{C}$ in saturated $\mathrm{NaHCO}_{3}$ buffer $(1.14 \mathrm{M}, \mathrm{pH} 8.15$; opaque bars), and with $5 \%$ (v/v) methanol $(\sim 1.3 \mathrm{M})$ at $40{ }^{\circ} \mathrm{C}$ in saturated $\mathrm{NaHCO}_{3}$ buffer (horizontal striped bars). Error bars reflect $95 \%$ confidence intervals $(n=4)$.

In situ product removal (ISPR) techniques could potentially be applied to address product inhibition/deactivation. The method of reactive crystallization would be particularly interesting because it could be implemented through the selection of an appropriate metal bicarbonate salt. In this way, the charged product anion could potentially precipitate from solution when bound to the metal cation without negatively affecting enzyme performance. Furthermore, the bicarbonate ion would also help buffer the $\mathrm{pH}$ during reaction presenting a potent 'self-healing' system. This method of reactive crystallization ISPR was recently demonstrated with a transaminase reaction to improve the thermodynamic equilibrium to favor product formation. ${ }^{26}$ Ultimately, product in 
the form of solid precipitates resulted in a product concentration in excess of $1 \mathrm{M}$. For the case of the rPLE reaction, two-liquid phase ISPR approaches would not be feasible because the substrate, being hydrophobic, would partition more strongly than the product into an organic phase. Instead, further focus could be made towards more expensive ISPR methods such as selective ion exchange resins $^{27,28}$ or charged membranes ${ }^{29}$. Another possibility could be to remove the product in an external loop through $\mathrm{pH}$ swing (precipitation) or cooling crystallization, although this is less likely to be feasible since the excess bicarbonate would need to be removed and such a system would also require a means to retain the biocatalyst from the harsh conditions in the external loop..$^{30,31}$ The reaction itself might be also further improved by the use of specific ionic liquids as additives. $^{32}$

\section{Conclusions}

Through the application of a standardized methodology relying on reaction trajectory analysis, it was concluded that the reaction was limited by mass transfer. This was due to the low solubility of substrate in the water-based medium. ECS-PLE06 is a robust enzyme that is highly thermostable and tolerant towards solvents ${ }^{25}$, therefore mass transfer limits could still potentially be reduced by increasing temperature or adding water-miscible co-solvents to this system to improve substrate solubility. This specific system also showcases the elegance of 'self-healing' systems where $\mathrm{pH}$ can easily be maintained by the reaction medium itself through an oversaturated, benign carbonate buffer reaction with product cation species.

In this work improved performance of ECS-PLE06 was achieved with final process metrics summarized in Table 2. These results point towards a promising biocatalytic reaction of up to $0.4 \mathrm{M}\left(75 \mathrm{~g} \cdot \mathrm{L}^{-1}\right)$ batches of product with an expected biocatalyst yield and productivity of $4.36 \mathrm{~g} \cdot \mathrm{g}_{\mathrm{biocat}}{ }^{-1}$ and $20.2 \mathrm{~g} \cdot \mathrm{L}^{-1} \cdot \mathrm{h}^{-1}$, respectively. Beyond this relatively high concentration limit, 
product inhibition or product induced inactivation will prevent further conversion of substrate. If higher product concentrations are required, then alternative ISPR techniques must be considered. Furthermore, substrate must be dosed in a fed-batch manner to avoid enzyme agglomeration and activity loss above $500 \mathrm{mM}$ substrate.

Table 2. Process performance metrics for the ECS-PLE06-catalyzed desymmetrization of 1 to 2.

\begin{tabular}{|c|c|}
\hline Reaction conversion & $100 \%$ \\
\hline Product concentration & $74 \mathrm{~g} \cdot \mathrm{L}^{-1}$ \\
\hline Space-time yield & $20.2 \mathrm{~g} \cdot \mathrm{L}^{-1} \cdot \mathrm{h}^{-1}$ \\
\hline Specific productivity & $1.20 \mathrm{~g} \cdot \mathrm{g}_{\text {biocat }}{ }^{-1} \cdot \mathrm{h}^{-1}$ \\
\hline Biocatalyst yield & $4.36 \mathrm{~g} \cdot \mathrm{g}_{\text {biocat }}{ }^{-1}$ \\
\hline
\end{tabular}

\section{Materials and Methods}

REAGENTS. All reagents were of analytical grade and supplied by Sigma-Aldrich (St. Louis, MO). Dimethyl cyclohex-4-ene-cis-1,2-dicarboxylate (1), (1S,2R)-1-(methoxycarbonyl)cyclohex4-ene-2-carboxylic acid (2) and lyophilized rPLE (ECS-PLE06; EC 3.1.1.1; $\geq 0.3 \mathrm{U} \cdot \mathrm{mg}^{-1}$ ) were kindly supplied by Enzymicals AG (Greifswald, Germany).

ACTIVITY ASSAY. The activity of pig liver esterase was quantified through spectrophotometric measurements of the degradation of $p$-nitrophenyl acetate ( $p$ NPA) to $p$ nitrophenolate. Reaction mixtures contained $850 \mu \mathrm{L}$ of phosphate buffer $(\mathrm{pH} 7.5,50 \mathrm{mM}), 50 \mu \mathrm{L}$ of enzyme stock solution and $100 \mu \mathrm{L}$ of $p$ NPA in DMSO $(10 \mathrm{mM})$. Initial rate measurements were taken at $400 \mathrm{~nm}\left(\varepsilon_{30}{ }^{\circ} \mathrm{C}=17759 \mathrm{~L} \cdot \mathrm{mol}^{-1} \cdot \mathrm{cm}^{-1}\right)$ over $100 \mathrm{~s}$ at $30{ }^{\circ} \mathrm{C}$. One unit $(\mathrm{U})$ of esterase activity was defined as the generation of $1 \mu \mathrm{mol}$ of $p$-nitrophenolate per minute under the standard activity 
assay conditions. Measurements were made using a UV-vis spectrophotometer (Specord 50, Analytik Jena AG, Jena, Germany). Reference samples contained distilled $\mathrm{H}_{2} \mathrm{O}$ and negative controls were performed in the absence of enzyme.

SMALL-SCALE APPARATUS. Small-scale reactions were performed in a $100 \mathrm{~mL}$ round bottom flask using a magnetic stirrer for mixing and an external water bath for temperature control at $40{ }^{\circ} \mathrm{C} .40 \mathrm{~mL}$ of saturated $\mathrm{NaHCO}_{3}$ buffer (pH 8.15) was used to control the pH. ECS-PLE06 $\left(\geq 0.3 \mathrm{U} \cdot \mathrm{mg}^{-1}\right)$ was dosed to this medium, and the reaction was started by the addition of $0.6 \mathrm{~g}$ of $1(80 \mathrm{mM})$. Samples $(500 \mu \mathrm{L})$ were taken periodically and concentrations of $\mathbf{1}$ and $\mathbf{2}$ were determined using the procedure detailed in the analytical methods section. Reaction progress could be indirectly followed by use of a $\mathrm{CO}_{2}$ bubble counter fixed to the top of the apparatus.

FED-BATCH 250 mL STIRRED TANK REACTOR. Fed-batch experiments were performed in a $300 \mathrm{~mL}$ glass jacketed stirred tank reactor (STR). $42 \mathrm{~g}$ of $\mathrm{NaHCO}_{3}$ (corresponding to $2 \mathrm{M}$ final concentration, which translates to a saturated solution with excess solid $\mathrm{NaHCO}_{3}$ ) was added with $1500 \mathrm{U}$ of ECS-PLE06 (6 U $\cdot \mathrm{mL}^{-1}$ final concentration) to $190 \mathrm{~mL}$ distilled $\mathrm{H}_{2} \mathrm{O}$. Temperature was maintained at $40{ }^{\circ} \mathrm{C}$ by use of an external CC-K6 cryostat (Huber, Offenburg, Germany) and mixing ensured by a pitched 4-blade turbine with overhead stirring motor at $300 \mathrm{rpm}$. pH was measured by an InLab Semi-Micro electrolyte sensor (Mettler Toledo, Colombus, OH) and was found to be $8.15 \pm 0.38$ (mean $\pm \mathrm{SD}$ ) over all experiments using the sodium hydrogen carbonate buffered system. $60 \mathrm{~mL}$ of substrate 1 (corresponding to a final concentration of $1.2 \mathrm{M}$ ) was fed by a R99-E syringe pump (Razel Scientific Instruments, Fairfax, VT) over the first 10 hours to make up a final reaction volume of $250 \mathrm{~mL}$. Triplicate samples $(500 \mu \mathrm{L})$ were taken periodically over $24 \mathrm{~h}$ and concentrations of substrate and product were determined using the procedure detailed in the analytical methods section. 
ANALYTICAL METHODS. Concentrations of $\mathbf{1}$ and $\mathbf{2}$ were quantified by GC-FID (TRACE 1310 Series, Thermo Fisher Scientific, Waltham, MA). Triplicate samples of $500 \mu \mathrm{L}$ were taken from reaction media and acidified with $500 \mu \mathrm{L}$ of concentrated $\mathrm{HCl}$ (1:1 volumes) to render 2 insoluble in the aqueous environment and to denature residual protein activity. Samples were then diluted and extracted with methyl tert-butyl ether (MTBE) containing n-decane $(25 \mathrm{mM})$ as an internal standard by vortexing on the highest setting and phase separation followed by centrifugation. $1 \mu \mathrm{L}$ of the organic phase fraction was injected into a TR-1701 column (30 m x $0.25 \mathrm{~mm}$ x $0.25 \mu \mathrm{m}$; Thermo Fisher Scientific, Waltham, MA) where the oven temperature was ramped from $130{ }^{\circ} \mathrm{C}$ to $200{ }^{\circ} \mathrm{C}$ at a rate of $5^{\circ} \mathrm{C} \mathrm{min}-1$ and thereafter held at an isotherm of $200{ }^{\circ} \mathrm{C}$ for $1 \mathrm{~min}$. Injector and detector temperatures were maintained at $250{ }^{\circ} \mathrm{C}$ throughout. The carrier gas flow rate was $1.2 \mathrm{~mL} \mathrm{~min}^{-1}$ with a split ratio of $35: 1$. Experimental substrate and product concentrations were determined using a standard curve generated by subjecting samples of known concentrations to the same acidification/solvent extraction procedure.

\section{AUTHOR INFORMATION}

\section{Author Contributions}

The manuscript was written through contributions of all authors. All authors have given approval to the final version of the manuscript.

\section{Funding Sources}

Funding by the German Federal Ministry of Education and Research (BMBF - Bundesministerium für Bildung und Forschung; project number: 031A123) and the German Research Foundation (DFG - Deutsche Forschungsgemeinschaft; LA 4183/1-1) is gratefully acknowledged. The 
authors thank the Technical University of Denmark (DTU) for financial support for one of us (MPM).

\section{Notes}

The authors declare no competing financial interest.

\section{ACKNOWLEDGMENT}

The authors thank Prof. Dr. Udo Kragl (University of Rostock, Germany) and Prof. Dr. Uwe Bornscheuer (University of Greifswald, Germany) for their ongoing support and fruitful discussions.

\section{REFERENCES}

(1) Sheldon, R. A.; Pereira, P. C. Biocatalysis engineering: the big picture. Chem. Soc. Rev. 2017, 46, 2678-2691.

(2) Straathof, A. J. J.; Panke, S.; Schmid, A. The production of fine chemicals by biotransformations. Curr. Opin. Biotechnol. 2002, 13, 548-556.

(3) Sheldon, R. A.; Woodley, J. M. Role of biocatalysis in sustainable chemistry. Chem. Rev. 2018, $118,801-838$.

(4) Woodley, J. M. Protein engineering of enzymes for process applications. Curr. Opin. Chem. Biol. 2013, 17, 310-316.

(5) Hughes, G.; Lewis, J. C. Introduction: Biocatalysis in industry. Chem. Rev. 2018, 118, 1-3.

(6) Choi, J-.M.; Han, S-.S.; Kim, H-.S. Industrial applications of enzyme biocatalysis: Current status and future aspects. Biotechnol. Adv. 2015, 33, 1443-1454. 
(7) Schmid, A.; Dordick, J. S.; Hauer, B.; Kiener, A.; Wubbolts, M.; Witholt, B. Industrial biocatalysis today and tomorrow. Nature 2001, 409, 258-268.

(8) Tufvesson, P.; Lima-Ramos, J.; Al Haque, N.; Gernaey, K. V.; Woodley, J. M. Advances in the process development of biocatalytic processes. Org. Process Res. Dev. 2013, 17, 12331238.

(9) Aldercreutz, P. in Organic Synthesis with Enzymes in Non-Aqueous Media; Wiley-VCH Verlag GmbH \& Co. KGaA: Weinheim, Germany, 2008.

(10) Meyer, H.-P.; Eichhorn, E.; Hanlon, S.; Lütz, S.; Schürmann, M.; Wohlgemuth, R.; Coppolecchia, R. The use of enzymes in organic synthesis and the life sciences: Perspectives from the Swiss Industrial Biocatalysis Consortium (SIBC). Catal. Sci. Technol. 2013, 3, 2940.

(11) Hollmann, F.; Arends, I. W. C. E.; Buehler, K.; Schallmey, A.; Buehler, B. Enzymemediated oxidations for the chemist. Green Chem. 2011, 13, 226-265.

(12) Noorman, H. in Fundamental Bioengineering; Wiley-VCH Verlag GmbH \& Co. KGaA: Weinheim, Germany, 2016; pp. 463-498.

(13) Stocks, S. M. in Microbial Production of Food Ingredients, Enzymes and Nutraceuticals; Woodhead: Cambridge, 2013; pp. 144-172.

(14) Nordblad, M.; Dias Gomes, M.; Meissner, M. P.; Ramesh, H.; Woodley, J. M. Scoping biocatalyst performance using reaction trajectory analysis. Org. Process Res. Dev. 2018, 22, 1101-1114. 
(15) Duggleby, R. G. Quantitative analysis of the time courses of enzyme-catalyzed reactions. Methods 2001, 24, 168-174.

(16) Blackmond, D. G. Reaction progress kinetic analysis: A powerful methodology for mechanistic studies of complex catalytic reactions. Angew. Chem. Int. Ed. 2005, 44, 43024320.

(17) Duggleby, R. G. Analysis of progress curves for enzyme-catalyzed reactions: Applications to unstable enzymes, coupled reactions and transient-state kinetics. Biochim. Biophys. Acta 1994, $1205,268-274$.

(18) Süss, P.; Illner, S.; von Langermann, J.; Borchert, S.; Bornscheuer, U. T.; Wardenga, R.; Kragl, U. Scale-up of a recombinant pig liver esterase-catalyzed desymmetrization of dimethyl cyclohex-4-ene-cis-1,2-dicarboxylate. Org. Process Res. Dev. 2014, 18, 897-903.

(19) Wohlgemuth, R. in Biocatalysis for Green Chemistry and Chemical Process Development; John Wiley \& Sons, Inc.: Hoboken, NJ, 2011; pp. 277-298.

(20) Boland, W.; Niedermeyer, U.; Jaenicke, L.; Görisch, H. Enantioselective syntheses and absolute-configurations of viridiene and aucantene, 2 constituents of algae pheromone bouquets. Helv. Chim. Acta 1985, 68, 2062-2073.

(21) Yun, S. Y.; Zheng, J.-C.; Lee, D. Concise synthesis of the tricyclic core of platencin. Angew. Chem. Int. Ed. 2008, 47, 6201-6203.

(22) Andreini, M.; Doknic, D.; Sutkeviciute, I.; Reina, J. J.; Duan, J.; Chabrol, E.; Thepaut, M.; Moroni, E.; Doro, F.; Belvisi, L.; Weiser, J.; Rojo, J.; Fieschi, F.; Bernardi, A. Second 
generation of fucose-based DC-SIGN ligands: Affinity improvement and specificity versus Langerin. Org. Biomol. Chem. 2011, 9, 5778-5786.

(23) Compton, T.; Gellman, S. H.; English, E. P.; Chumanov, R. S. Beta-Polypeptides that Inhibit Cytomegalovirus Infection WO2006099170, 2006.

(24) Süss, P.; Borchert, S.; Hinze, J.; Illner, S.; von Langermann, J.; Kragl, U.; Bornscheuer, U. T.; Wardenga, R. Chemoenzymatic sequential multistep one-pot reaction for the synthesis of (1S,2R)-1-(methyoxycarbonyl)cyclohex-4-ene-2-carboxylic acid with recombinant pig liver esterase. Org. Process Res. Dev. 2015, 19, 2034-2038.

(25) Hinze, J.; Süss, P.; Strohmaier, S.; Bornscheuer, U. T.; Wardenga, R.; von Langermann, J. Recombinant pig liver esterase-catalyzed synthesis of (1S,4R)-4-hydroxy-2-cyclopentenyl acetate combined with subsequent enantioselective crystallization. Org. Process Res. Dev. 2016, 20, 1258-1264.

(26) Hülsewede, D.; Tänzler, M.; Süss, P.; Mildner, A.; Menyes, U.; von Langermann, J. Development of an in situ-product crystallization (ISPC)-concept to shift the reaction equilibria of selected amine transaminase-catalyzed reactions. Eur. J. Org. Chem. 2018, 18, 2130-2133.

(27) Bechtold, M.; Makart, S.; Heinemann, M.; Panke, S. Integrated operation of continuous chromatography and biotransformations for the generic high yield production of fine chemicals. J. Biotechnol. 2006, 124, 146-162. 
(28) Meyer, L.-E.; Plasch, K.; Kragl, U.; von Langermann, J. Adsorbent-based downstreamprocessing of the decarboxylase-based synthesis of 2,6-dihydroxy-4-methylbenzoic acid. Org. Process Res. Dev. 2018, 22, 963-970.

(29) Strathmann, H. Electrodialysis, a mature technology with a multitude of new applications. Desalination 2010, 264, 268-288.

(30) Buque-Taboada, E. M.; Straathof, A. J. J.; Heijnen, J. J.; van der Wielen, L. A. M. In situ product removal using a crystallization loop in asymmetric reduction of 4-oxoisophorone by Saccharomyces cerevisiae. Biotechnol. Bioeng. 2004, 86, 795-800.

(31) Buque-Taboada, E. M.; Straathof, A. J. J.; Heijnen, J. J.; van der Wielen, L. A. M. In situ product recovery (ISPR) by crystallization: basic principles, design, and potential applications in whole-cell biocatalysis. Appl. Microbiol. Biotechnol. 2006, 71, 1-12.

(32) Wallert, S.; Drauz, K.; Grayson, I.; Gröger, H.; Dominguez de Maria, P.; Blom, C. Ionic liquids as additives in the pig liver esterase (PLE) catalysed synthesis of chiral disubstituted malonates. Green Chem. 2005, 7, 602-605. 


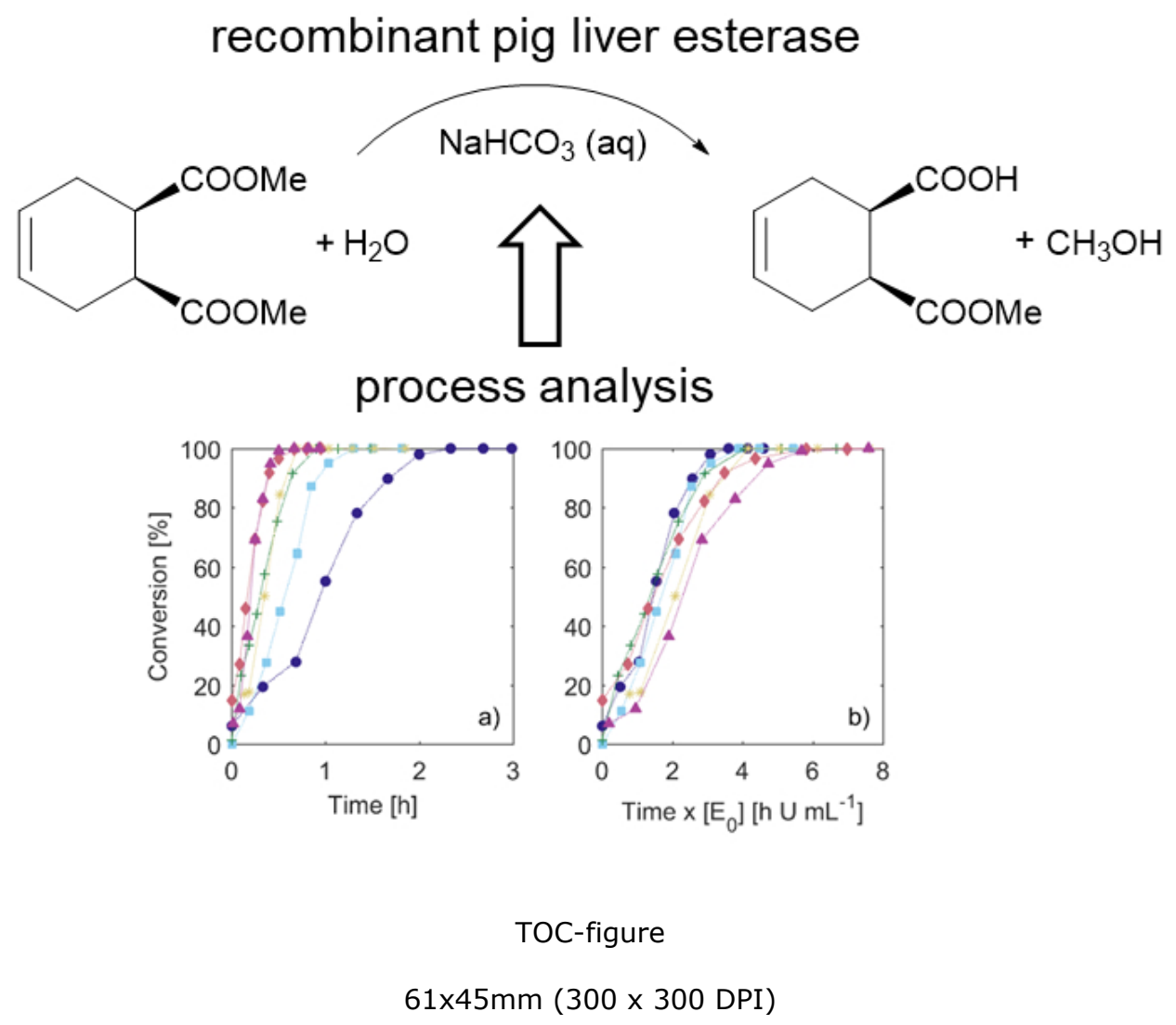

ACS Paragon Plus Environment 